\title{
SMALL MONEY, BIG PROBLEMS: HOW AN INVESTIGATION ON SMALL LATIN AMERICAN REPUBLICS SHAPED THE FINANCIAL MARKET FOR SOVEREIGN DEBT IN THE 19TH CENTURY
}

Pequeno dinheiro, grandes problemas: como uma investigação sobre pequenas repúblicas latino-americanas moldou o mercado financeiro da dívida pública no século XIX

Pequeño dinero, grandes problemas: cómo una investigación sobre las pequeñas repúblicas latinoamericanas moldeó el mercado financiero de la deuda soberana en el siglo XIX

José Augusto Ribas Miranda

http://dx.doi.org/10.1590/\$2178-14942017000100004

José Augusto Ribas Miranda é mestre e doutorando em História pela Pontifícia Universidade Católica do Rio Grande do Sul (joseribas50@hotmail.com).

Artigo recebido em 30 de novembro de 2016 e aprovado para publicação em 2 de fevereiro de 2017. 


\begin{abstract}
In 1875 the British Parliament set up a Committee to investigate frauds on loans underwritten by British and French banks to the Republics of Honduras, Costa Rica, Santo Domingo and Paraguay, reaching an amount of $£ 12$ million. The reports of the Committee and the press coverage issue revealed financial malpractices by banks and diplomats in order to induce millionaire defaults at expense of the bondholders, whilst the loan agents were living in luxuriant mansions in southern France. After the investigation, these shoddy practices were exposed to the public, reshaping the loan business for the rest of the century.
\end{abstract}

KeYwORDs: Latin America, high finance, corruption.

\title{
Resumo
}

Em 1875 o Parlamento britânico instaurou um Comitê para investigar fraudes cometidas em empréstimos subscritos por bancos britânicos e franceses para as repúblicas de Honduras, Costa Rica, Santo Domingo e Paraguai em um montante de $f 12$ milhões. Os relatórios do Comitê e a cobertura da imprensa especializada revelaram usuais práticas ilegais de bancos e diplomatas buscando induzir moratórias milionárias à custa dos investidores e dos orçamentos dos Estados envolvidos, enquanto os negociadores compravam luxuosos castelos no sul da França. Após as investigações essas práticas fraudulentas foram expostas ao público, transformando o mercado de empréstimos soberanos pelo resto do século XIX.

PalAVRAS-CHAVE: América Latina, finanças, corrupção.

\section{RESUMEN}

En 1875 el Parlamento británico estableció un comité para investigar el fraude en los préstamos contraídos por las Repúblicas de Honduras, Costa Rica, Santo Domingo y Paraguay en una cantidad de $£ 12$ millones. Los informes de la Comisión y la cobertura de la prensa revelaron prácticas ilegales de los bancos y diplomáticos que buscaban inducir moratorias millonarias a expensas de los inversores y los presupuestos de las Repúblicas, mientras que los negociadores vivían en lujosos castillos en Francia. Después de estas investigaciones, las prácticas fraudulentas fueron expuestas al público, transformando el mercado de préstamos para el resto del siglo 19.

Palabras clave: América Latina, finanzas, corrupción. 


\section{THE LOAN BOOM OF THE $1870 \mathrm{~S}$}

$\mathrm{T}$ he 1870 s were a busy decade for the loan business in European financial markets. Prior to the 1873 financial crisis, lenders were in an optimistic mood, looking for profitable investments in Southeast Asia, Africa, and Latin America. The age of global investments had reached its apex, with the European financial markets at the centre. Never before had choosing portfolio investments around the world been so easy and common. Investors based in London, Paris, and Berlin could see a global investment scenario opening before their eyes.

The approximate total of British investments in Latin America more than doubled between 1865 and 1875 , reaching an average of $£ 175$ million sterling. The major share of these investments went to government securities in the form of large loans.

Latin American governments were not beginners in the European and British financial markets. The first wave of public loans occurred in the 1820s during the first years of the Latin American countries as independent political units. Initially the majority of loans were taken to fund the wars of independence and to establish bureaucracies in the new states. The promise of economic restructuration after the wars faded and the new states were brought down by internal conflicts and economic insolvency, leading to the first big wave of defaults in modern financial history. ${ }^{1}$

This first default wave bequeathed more than two decades of financial ostracism in the European financial markets to Latin American governments. The only exception was the Brazilian empire, which managed to service all its debts from the 1820s, and was the only Latin American country to contract new loans in the 1830s and 1840s. The second wave of loans to Latin America began in the 1860s with its recovery from internal conflicts and the development of commodity export complexes. The advent of new transportation technologies (steamships and railways) opened and linked the hinterlands to the ports and to world trade. The expressive increase in exports reopened the doors of financial centres to Latin American securities seeking developmental loans to enhance their export sectors.

European credit was cheap and plenty in the 1870s. The increase in the volume of world trade, especially European trade, created a large capital surplus in the main European economic centres. In Britain the savings rate reached an average of $9 \%$ of GDP between 1840 
and 1870, while loans climbed from 1.7\% to 7.6\% of British GDP (Ferguson, 2001: 297; Floud and McCloskey, 1994: 175). The City of London became the head of the modern financial world, with the British banks as its arms.

In the 1870s there were some important financial novelties that cheapened credit. These new developments in modern finance laid the foundations for an impressive outflow of capital in a cycle that would end with the 1873 financial crisis.

New communication and transportation technologies made news and and prices to circulate quicker. As information about financial institutions become more widely available through, for instance, the publication of balance sheets, and as reputations become better known, depositors and shareholders required banks, on average, to hold less capital. The more information about bank proceedings, the less capital holdings that were necessary. As money markets developed, they were able to hold some fractions of their assets in liquid securities instead of only liquid cash and illiquid loans. That made credit cheaper, attracting a wide range of borrower states, from east and west. (Grossman, 2007: 143)

In addition, during the previous fifteen years the British parliament had approved two important bills. The Joint Stock Act of 1854 and the Limited Liability Act of 1855 not only gave protection and stimulus to the formation of new companies in the Stock Exchange but also transformed financial markets with the rise of the joint stock banks. These new joint stock banks were eager to gain a share in the loan business among the traditional and familiar banking houses such as Rothschild and Baring's, serving new and untried countries in the capital market, increasing competition with other banks and making credit more available and cheaper (Chapman, 1984). This mad run for fresh loan deals with new states by smaller banks and financial houses was one of the reasons for the big scandals and frauds of the 1870s financial markets.

Government bonds were also rising in investor preferences. With railway and other company stocks reaching a saturation point in the 1860 s, lending to governments seemed a more profitable way to allocate investors' hard earned savings. After the bankruptcy of the well-established bill broker and acceptance house Overend, Gurney \& Co in 1866, the London financial market turned sour for the next two years. The firm, founded in 1775 in Norfolk, became the largest discount house in Britain, bigger than its next three competitors combined. In 1850 the volume of commercial bills discounted by the firm amounted to half the total yearly British funded debt (Sowerbutts, Schneebalg and Hubert, 2016). With the expansion of its business in the 19th century, the new board of directors tried to explore the new and dynamic business of company loans. After a complicated time for company loans (especially railway companies) in the 1860s, with the securities markets reaching a saturation point in 
terms of railway shares, the firm saw itself in a delicate position with a series of bad loans in its portfolio. After an unsuccessful attempt to go public in 1865, Overend, Gurney \& Co declared bankruptcy in May 1866, results in hundreds of investors and savings account holders losing their money.

This banking crisis led to an increase in the Bank of England discount rate, an uninvesting period for the British industry and a consequent inflow of bullion, increasing the British savings rate and cheapening the credit for next decade. ${ }^{2}$ According to a contemporary witness and analyst, Walter Bagehot, the high savings rate reached by the British public after the failure of Overend, Gurney \& Co helped government securities find a welcoming environment at the London Stock Exchange, "That made the 1870s a special and short age of cheap credit, as much internal as external" (Bagehot, 1873: 142-46).

With abundant credit and rising commodity prices, a new loan frenzy began. In the Middle East, the Ottoman Empire became heavily dependent on fresh capital inflows from European Banks. After the Crimean War, the debt burden was only made bearable by the influx of fresh capital from new British and French loans. Egypt was also a very important borrower due the newly built Suez Canal. The maintenance of these two Middle Eastern states was strategic for the politics of the Western great powers, so British and French Banks and financial houses acted to support these governments and to make handsome profits from these loans. Until the default crisis of the 1870s the Ottomans contracted approximately $£ 100$ million in loans and Egypt another $\mathrm{f} 63$ million in London alone (Jenks, 1938: 421-24). ${ }^{3}$

In Latin America it was no different. The region absorbed a quarter of all British capital for sovereign loans between 1850 and 1880. While the first wave of loans for the region was intended to pay soldiers and to buy military supplies, the second wave was much more successful, in its goal of improving continental infrastructure.

In the middle of the century commodity exports by Latin American countries surged. With the majority of the internal problems settled, the region witnessed a rapid increase in the exports of agricultural and mineral products. A green revolution in Europe created a significant demand for Peruvian natural fertilizer, guano. Copper from Chile, silver from Mexico, sugar and tobacco from the Caribbean and Brazilian coffee reached the European markets on an unprecedented unseen scale. In Britain alone, imports of raw materials from the region increased by 300\% between 1850 and 1880. (Marichal, 1989: 68-97) With export sectors rapidly developing, Latin American countries became monetized, and were able to turn again to European financial markets looking for fresh loans.

Latin American Governments were looking for money for infrastructure projects to enhance their exports sectors, propelled by the favourable economic momento of 1850-1870. 
The biggest borrower, Peru, had more than $\mathrm{f} 44$ million in debts with British and French houses, followed by Brazil ( $€ 24$ million) and Mexico ( $€ 23$ million). Under the illusions of the guano wealth, the Peruvian Government contracted two big loans in 1870 and 1872 with a syndicate of British and French banks to build two monumental railways to cross the Andes at the sum of $£ 31$ million payable in 30 years. The Chilean government made three infrastructure loans $(1870,1873,1875)$ for railway building and urban public works in the capital, Santiago. Furthermore, the province of Buenos Aires contracted more than $\mathrm{f} 3$ million for improvements in Buenos Aires harbour in mid-1870s.

Having set the tone, the newcomers also joined the great game of finance in London and Paris. Small countries, previously unknown by European investors, floated large loans on the London Stock Exchange seeking fresh capital for infrastructure projects, similar to the larger and more solvent economies. Despite the inexpressive trade volume of these countries with European markets, their trade growth rate was nonetheless satisfactory. In Central America, exports to Britain rose tenfold between 1850 and 1873, reaching $f 1.4$ million sterling. Bolivia previously had not even existed in British trade accounts, but reached $\mathrm{f1}$ million of exports in late 1872, as much as Colombia in the same year (Platt, 1972: 320-21).

Bolivia, Paraguay, Santo Domingo, Costa Rica, Honduras and Guatemala were listed on the London Stock Exchange as investment options, advertising their natural riches and profitable railway lines with rates of return rates up to $10 \%$ on capital invested.

The presence of these governments' bonds was only made possible by the effort of the smaller banks, eager to reap profits on dubious business that would never be underwritten by the traditional and powerful banks of the City of London, such as N. M. Rothschild \& Sons or Baring Brothers \& Co. Less reputable banking houses, such as Bischoffsheim \& Goldschmidt, London County Bank, and Thomson Bonar \& Co took advantage of the favourable economic moment, the willingness of these governments to borrow large sums, and the eagerness of investors for highly profitable business to create a network of interests involving banks, government agents, and railway contractors. The results were often large loans taken at the expense of bondholders and state treasuries to the benefit of the banks and the loan negotiators. As one insider of the haute finance once stated:

It is here that the distinction is to be found between honest and dishonest financing. The honest financier does not present to the public for his own profit, a business in which subscribers are not likely to find a profit for themselves. The dishonest financier, on the contrary, is content when he has foisted his wares on the public, indifferent as to the ultimate result. In the teeth of experience, the public believes in the promises of a prospectus. This is well ascertained, and the weakness of humanity has been well worked (Wolff 1908, vol II: 60). 
These malpractices found fertile ground in Latin America, where inexperienced countries met inexperienced investors through 'dishonest financiers' at the expense of all involved apart from financiers and diplomatic agents.

Between 1867 and 1872 small Latin American republics contracted ten loans with less reputable banks, producing the second wave of defaults in the region, joining the global financial debacle of the largescale defaults of the Ottomans, Egypt, and Peru. These investments had shown themselves to be unsustainable as news of the financial insolvency of the countries reached investors along over the years. Countries with a yearly income of $f 200,000$ were burdened with servicing a debt twice as large, as was the case of Honduras.

Starting in 1873 Bolivia, Costa Rica, Guatemala, Honduras, Paraguay, and Santo Domingo stopped servicing their debts, leaving the bondholders with more than $f 12$ million of valueless papers in their hands.

\begin{tabular}{|c|c|c|c|c|}
\hline & $\begin{array}{l}\text { Interest Rate } \\
\text { and Date of Issue }\end{array}$ & $\begin{array}{l}\text { Nominal Value } \\
\text { (f thousands) }\end{array}$ & Default & Bank \\
\hline Bolivia & $6 \%-1872$ & 1,654 & 01.1875 & Lumb, Wanklyn \\
\hline Costa Rica & $\begin{array}{l}6 \%-1871 \\
7 \%-1872\end{array}$ & $\begin{array}{r}940 \\
2,362\end{array}$ & $\begin{array}{l}11.1874 \\
04.1874\end{array}$ & $\begin{array}{l}\text { Bischoffsheim } \\
\text { Bischoffsheim }\end{array}$ \\
\hline Guatemala & $6 \%-1869$ & 469 & 04.1875 & Thomson, Bonar \& Co \\
\hline Honduras & $\begin{array}{r}10 \%-1867 \\
7 \%-1869 \\
10 \%-1870\end{array}$ & $\begin{array}{l}1,000 \\
2,177 \\
2,243\end{array}$ & $\begin{array}{l}01.1873 \\
03.1873 \\
01.1873\end{array}$ & $\begin{array}{l}\text { Bischoffsheim } \\
\text { Dreyfus \& Co } \\
\text { Dreyfus \& Co }\end{array}$ \\
\hline Paraguay & $\begin{array}{l}8 \%-1871 \\
8 \%-1872\end{array}$ & $\begin{array}{l}957 \\
548\end{array}$ & $\begin{array}{l}06.1874 \\
07.1874\end{array}$ & $\begin{array}{l}\text { Robinson \& Fleming } \\
\text { Robinson \& Fleming }\end{array}$ \\
\hline Santo Domingo & $6 \%-1869$ & 714 & 01.1873 & Peter Lawson \\
\hline
\end{tabular}

(Marichal, 1989: 120)

These defaults were a bitter blow to British investors. With promises of high profit rates in a short time, the banks involved usually attracted inexperienced investors - widows, clerks, shopkeepers - looking for more than the $3 \%$ return of British treasury bonds, the Consol.

Latin America had previously been the stage for large corruption scandals involving state loans. The most impressive case took place in Central America in 1822 when a Scottish soldier and adventurer, Gregory McGregor, deceived hundreds of investors and settlers. In the middle of the Latin American revolutions, McGregor, after many years fighting alongside Francisco de Miranda and Simón Bolivar's armies in New Granada, returned to Europe advertising the wonders of the prosperous but underdeveloped country of Poyais, on the Mosquito shore, neighbouring the British colony of Belize. MacGregor was self-designated 'Cazique of Poyais' 
under the authority of the so-called 'King of Poyais,' George Federic Alexander, a tribal leader in the tropical forest of Mosquito Shore. Launching a sophisticated scheme, McGregor drafted a constitution, created a fictional Poyais Bank, and established a 'Poyer' embassy in London to sell small farms to British settlers. He also launched a daring loan of $£ 200,000$ on the London Stock Exchange to enhance the country's infrastructure for the arriving settlers.

The scheme did not last long. In 1825 the news of the abandoned settlers reached the British press, where dozens of families perished under the harsh tropical conditions. McGregor fled to France, and then to Venezuela, leaving hundreds of bankrupt investors and tarnishing the reputation of Latin American countries for investment. ${ }^{4}$

Although these defaults were substantially smaller than the Middle Eastern and Peruvian ones - $€ 12$ million against more than $\mathrm{f} 200$ million - the indecency of the banks and government agents' practices, misleading advertising, and the hidden and underhand deals between government agents and banks attracted attention to the sharp practices commonly in use in high finance. The British parliament installed a Special Committee in 1875 to investigate the Honduran, Dominican and Paraguay loans, revealing Latin America to be a laboratory for corrupt schemes and market rigging.

\section{THE HONDURAN LOANS}

I n 1875 the British Parliament set up the Select Committee on Foreign Loans (Select Committee on Loans to Foreign States, 1875) to investigate malpractices and corruption in loans contracted by the republics of Honduras, Santo Domingo and Paraguay in default at the time, depriving hundreds of bondholders of their hard earned savings and tarnishing the reputation of the London financial market. Investigations continued for a year followed by an eager press and by angry bondholder associations. The most symbolic case was of Honduras, due the amount of the loans contracted and the impressive sums received by agents at the expense of bondholders and the Honduran treasury.

The Honduran Government had authorized the contracting of three loans in 1867, 1869, and 1870 to build a transoceanic railway, connecting the Atlantic harbour of Puerto Caballos to its Pacific counterpart at Golfo de Fonseca. The intention was to create an alternative route for the ever growing Atlantic-Pacific trade, especially after the opening of the California and Australia gold mines, of great interest to European trade centres.

The loans were contracted by the Honduran ministers in London and Paris, Don Carlos Gutierrez and Don Victor Herrán, in partnership with the French 'financier' Charles Joachim Lefevre. Lefevre was the central character in the whole Honduran drama. He was 
specially picked by Gutierrez and Herrán not for the noblest, but for more practical reasons: his knowledge of the mechanics of the bond market and the moods of stock exchanges.

Lefevre and Gutierrez made a deal with Bischoffsheim \& Goldschmidt of London to contract the loans, with the aim of finding an established institution for underwriting the operation, giving it more credibility and increasing its commercial appeal. In 1867 the first loan of $£ 1,000,000$ at $10 \%$ interest with a sinking fund of $3 \%$ was offered to the public for the construction of the Transoceanic Railway. In the prospectus a Board of Trustees - composed by respectable engineers and London businessman, Don Gutierrez, Don Herran, Lefevre, and Bischoffsheim \& Goldschmidt - advertised the advantages of an Atlantic-Pacific connection through a railway, and the inevitability of the profitability of the business. In order to increase its credibility, the prospectus stated that the line had been surveyed by a British engineer, confirming that "the harbours of both Termini are unexceptionable, and that the road can be constructed without any sharper curve of heavier gradients that are to be found in existing lines over which Locomotives work without difficulty". ${ }^{5}$

As guarantees for this large enterprise, the Honduran Government - "the most interested party" - offered the state's customs duties, the mortgage of all domains, estates, and forests (containing mahogany, indigo, cotton and other tropical products), in addition to the revenues of the Railway when it began to operate.

With such guarantees and a high rate of return of $10 \%$, the Honduran deal turned into a hit among the inexperienced investors and opportunistic brokers. The debt kept being serviced and the first 20 miles of railway track were under construction. Moreover, for at least six months, the bonds of the Honduran loan were well quoted on the London Stock Exchange.

Within eighteen months a new loan of $f 2$ million at $7 \%$, with a sinking fund of $3 \%$ was contracted in London and Paris. The Honduras enterprise was demanding new cash inflows due the hardships of building a railway in a tropical rainforest, according to the contractors. One year later, a new $\mathrm{f} 2.5$ million loan was launched to refinance the old debts and to continue the Railway to its 30th mile.

In 1872, the Honduran agents, Gutierrez and Lefevre tried again to use the Honduran government to launch a new fantastic loan of $£ 15$ million (!) to build a Transoceanic Ship Railway: an incredible railway able to transport entire cargo ships across Honduras, connecting the sea trade routes by land. This loan was such a public embarrassment, that Gutierrez had to withdraw it and Lefevre fled to France, chased by the bondholders. One year later the Honduran government declared its incapacity to service its outstanding debt of $£ 6.5$ million with yearly revenues of a meagre $f 200,000$. 
The Committee's investigations of the Committee, examining the actions of those involved, uncovered a complex and sophisticated corruption scheme only possible in weak governments, as in Hondurans and the other small Latin American republics.

\section{ThE INVESTIGATION}

I

n 1875 the Select Committee presented the results of its investigations, revealing the

spurious dealings related to the 1870 loan, clarifying various malpractices. In the two days following the Initial Public Offering of the 1870 loan the representatives of the Honduran Government, Lefevre and Bischoffsheim, signed three contracts hidden from investors' eyes. In these contracts, Bischoffsheim \& Goldschmidt quietly renounced their liabilities regarding the underwriting of the loan in favour of Lefevre. Lefevre was to be in charge of selling the bonds to the public and paying the premiums of $10 \%$ to the bondholders. Bischoffsheim \& Goldschmidt would receive a total sum of $£ 180,000$ just for 'lending' its name to the operation, as stated in the prospectus. Moreover, although the loan was issued at $\mathrm{f} 80$ per share, this contract gave Lefevre the right to buy the bonds first for $f 75$ and to sell them to the public afterwards at the pre-established price of $\mathrm{f} 80$.

After the signing of these three secret contracts, the initial allotment was sold on the London Stock Exchange at the price of $£ 80$. In order to give the business a more solid image, Gutierrez bought two shipments of mahogany in Honduras from a private source and delivered them to Bischoffsheim \& Goldschmidt to be sold in London, advertising the operation in the City newspapers. The Bank was already deprived of any liability following the secret contracts, but the receiving and selling of Honduran woods was a message for investors that the guarantees for the loan were being put in practice and the investment was safe as any European one.

Since the three loans were merged in one big operation within the 1870 loan, all the proceedings from the last loan were directly linked to servicing the older bonds of 1869 and 1867.

In 1870 and 1871 Lefevre hired the Londoner broker firm Barclay's and an army of between 50 and 100 brokers and jobbers to rig the market for Honduran bonds. With the bonds in his hands, Lefevre ordered this army to buy and sell the bonds on the London Stock Exchange to simulate a high volume of deals, keeping the price of the Honduran bonds at a premium value, quoted above $\mathrm{f} 80$ and $f 90$ for months. According to one witness, one broker alone bought and sold the whole $\mathrm{f} 2.5$ million loan once during the process. ${ }^{6}$

When the bonds reached a premium value, Lefevre started to sell them slowly to the public. In addition, the first withdrawals of bonds from the market (i.e., the repurchasing of 
the bonds by the Honduran Government using the sinking fund) were made in 1871, where Lefevre pocketed $\mathrm{f} 25$ per withdrawn share, since the withdrawals were made at face value. Moreover, Lefevre had not even paid for his bonds since he was in charge of the selling and distribution after the secret contracts with Bischoffsheim \& Goldschmidt. All the profits were made without Lefevre spending a single penny of his own.

In 1872 Lefevre and Gutierrez's final gamble went sour. In January, the agents tried to launch the fantastic $\mathrm{f} 15$ million Transoceanic Ship Railway loan, which was also intended to work as a refinancing loan, withdrawing the older bonds from 1867, 1869 and 1870 loans in exchange for the new bonds and the continuity of a much more daring railway plan, intended to carry cargo ships of up to 2,000 tons weight. According to the contractors:

Were the Line once completed, the profits which its working would produce, the value which the uncultivated lands on each side of the line would acquire, the exportation of the timber from the extensive forests which it traverses, and the mines in the vicinity of the Line, well managed, would be more than sufficient to make satisfactory arrangements with the bondholders, and to reduce the debt nominally contracted to equitable terms (Ferro, 1875: 39).

This was Lefevre and the Honduran agents' final attempt to propose a new and daring loan to British investors. As soon as the prospectus was listed on the London Stock Exchange, the Corporation of the Foreign Bondholders (CFB $)^{7}$ intervened, questioning the arrangements of the loan. The Council questioned why the contractors had not contracted a Bank to underwrite the loan, and if they had done so, why it was not stated in the prospectus. The CFB also ask Gutierrez to specify the procedures of exchange of the old bonds for the new ones, casting suspicions on such a big loan from a small and obscure Latin American Republic already $£ 6$ million in debt. ${ }^{8}$

Five months later, Gutierrez withdrew the loan from the London Stock Exchange. The following news were not good either. Gutierrez had to state the incapacity of the Honduran government to honour its debts and suspended the payment of interest and the sinking fund. The construction site in Honduras was abandoned due to a lack of payments, and the engineers sued the government in London. Honduran bonds on the Stock Exchange plummeted from $\mathrm{f} 80$ to less than $\mathrm{f} 6$ and Mr. Lefevre fled to France.

In 1875 the investigations discovered that Lefevre had been charged with financial crimes in France in 1858 and sentenced to two years in prison. Moreover, he also used variations of his name, such as C.J. Lefevre, C. Lefevre, or just Chevalier Lefevre to perpetrate his misdeeds.

According to the Committee, Lefevre managed to receive $£ 955,398$ from his Honduran schemes. Bischoffsheim \& Goldschmidt received at least $£ 180,000$ for only 
lending their name to the previous operations. There was no evidence of the involvement of the Honduran Agents in the scheme, but the French press noted that Don Victor Herran had bought the sumptuous Château Beaumont in Cussac-en-Medoc near Bordeaux in 1872 (Bourdariat, 2013: 172). The losers were the unwary bondholders and the Honduran Government, who recovered only $£ 40,000$ of all the nominal capital, and had to account for an outstanding debt of more than $\mathrm{f} 6$ million, 30 times larger than the country's revenues. The Honduran debt would take more 30 years to be refinanced before the republic could contract new loans.

\section{Consequences}

$\mathrm{T}$ he press took a lot of interest in the case. Financial papers urged the use of the Central and South American cases as an example of how not to operate in the financial markets. The Times' judgment was harsh:

If a novelist were to sit down to satirize the speculative practices of the time, we may imagine him selecting Honduras and Costa Rica, Santo Domingo and Paraguay, as the field of his fictitious enterprises. Yet it is in connexion with these obscure and half-civilized regions that operations involving immense profits to those engaged in them have been conducted. ${ }^{9}$

The lessons for financial markets were clear. The small Latin American Republics were in the perfect place and time to be affected by this kind of scheme. Although these practices proved neither to be the first and last of their kind in the financial markets, the Special Report from the Select Committee for Foreign Loans was the first profound public investigation of a highly non-regulated market like the British bond market. There was such public embarrassment in London financial circle that one witness said that the Prime Minister Disraeli subtly tried to "burke the whole enquiry" (Wolff, 1908, vol II: 55).

Latin America had a specific place in 19th century financial markets. As a region composed of independent governments with a European style of doing business, they differed from the most others borrowers, such as colonial governments or 'tutored' borrowers such as Persia, Egypt, and the Ottomans. The absence of geopolitical interests in these small countries also led the investigations to follow a more technical path.

In addition, the political weakness of the countries also helped the investigations, turning them into a showcase for malpractices in the financial markets. Although diplomatic agents could not be charged due to their diplomatic immunity, they felt the pressure to 
cooperate with the investigations and even to recognize some of the malpractices. Gutierrez ordered the writing of an 'Historical Account' of all the Honduran loans and procedures, widely used in the committee's investigations. He also testified twice in the trials, shedding light on some unclear details about the loan conversions. Such participation would be unimagined by proud Ottoman or Egyptian diplomats. Moreover, the pressure exerted by the Committee and the CFB would hardly have been accepted by the Foreign Office if more significant geopolitical interests had been implicated.

Better safety measures were demanded for new loans listed on the London Stock Exchange. Foreign loans could not be the subject of court cases since they were related to independent governments and not just registered companies. The Committee made a range of suggestions taking into account the lessons from the Latin-American scandals. First, they asked for a complete balance sheet of revenues and expenditures for the three previous years. More details on loan collaterals were demanded, including stating the net value of the exploitation of the forests, mines and land of these countries. In addition, they asked for the direct involvement of the head of state in such deals, instead of its diplomatic agents and their partners - such as Lefevre.

These suggestions were not accepted by the Board of the London Stock Exchange. Even the press was opposed, advocating a more liberal spirit and warning unwary investors of the dangers and their own responsibility in buying the securities of foreign governments. Nevertheless, important lessons were taken for the financial system as a whole in relation to regarding market rigging and price fixing. The Economist magazine was astonished by the whole narrative and how Lefevre managed to create such inflated prices for valueless papers:

Still, after every possible abatement, the narrative is very wonderful; it will astonish even experienced men of business to find such things can happen, and it will amaze theoretical economists to find how much 'market price,' with which they have dealt as something regular and controllable can, even for a considerable time, be arranged by speculators, and guided by them to suit the very worst of purposes..$^{10}$

The cases also show the high level of understanding of Haute Finance by the Latin American agents. They learned how to use European partners to create fake credibility in order to attract greedy investors looking for a $10 \%$ profit rate. Nevertheless, the consequences were the worst for the countries who saw all their properties mortgaged to pay the bondholders. The Paraguayan Government had to give 2,000,000 hectares of arable lands to bondholders to reduce its outstanding debts from $f 1.5$ million to $£ 800,000$. Costa Rica had to refinance 
her debt in 1885 , floating another $f 2$ million loan and also had to sell land and the nearly complete railway. Santo Domingo received only $5 \%$ of net proceeds of the loan. Facing such a bad result, its Congress repudiated the loan, leading to complications with European and American Governments. (Marichal, 1989: 120).

This was the last time that Latin America was treated 'gently' by lender countries. Despite the harsh renegotiations, no gunboats were sent to Puerto Caballos or Asuncion. The Foreign Office refused to deal directly with the governments, dismissing it as a bondholder issue only. In the 20th century the Central American Republics felt much harsher pressure from the United States, resulting in direct intervention as in the Cuban, Dominican, and Haitian cases in the 1920s. (Marichal, 1989: 171)

In the 1870s Latin America was an important place of investment for surplus European capital. The very fact that these schemes managed to extract such impressive amounts of money using small and poor countries illustrates the global place of Latin America in the 19th century economic context.

\section{Notes}

1 For a complete account of the first Latin American default wave, see Dawson (1990).

2 The average discount Bank of England discount rate for the 1860s was $4.18 \%$, while for the next decade, with plenty credit in the London market, the average discount rate fell to 2.98\% (Homer and Sylla, 2005: 160).

3 David Landes describes how European Banks took control of Ottoman and Egyptian finance in the 19th century and the subsequent consequences for world finance (Landes, 1958).

4 A complete account of the Poyais scheme can be found in Sinclair (2003).

5 Honduras ten percent Government Railway Loan 1867. Stock Exchange, Loans, and Companies Prospectuses nr. 147 - Guildhall Library, London.

6 The Economist 14.08.1875.

7 The Council of the Corporation of Foreign Bondholders was the most prestigious and effective Bondholders association in Britain for over 100 years. Founded in 1869, they represented the interests of bondholders against defaulter governments, exerting pressure on the Foreign Office and Parliament to obtain payments for the servicing of debts. For more on the CFB and its role in 19th century finance, see Mauro and Yafeh (2003).

8 Honduras ten percent Government Ship Railway Loan 1872. Stock Exchange, Loans, and Companies Prospectuses nr. 147 - Guildhall Library, London.

9 Times 31.01.1875.

10 The Economist, 14.08.1875. 


\section{SOURCES}

The Economist - 1875 .
The Times - 1875.

Honduras ten percent Government Ship Railway Loan 1872. Stock Exchange, Loans, and Companies Prospectuses nr. 147 - Guildhall Library, London.

FERRO, Ramon de Silva. Historical Account of the mischances in regard to the construction of a railway across the Republic of Honduras. London: C.F Hodgson, 1875.

SELECT COMMITTEE ON LOANS TO FOREIGN STATES. Special report and report from the Select Committee on Loans to Foreign States with the proceedings of the committee. 1875.

\section{References}

BAGEHOT, Walter. Lombard Street: a description of the Money Market. 3rd. ed. London: Henry S King \& Co, 1873.

BOURDARIAT, Jean. Quinze ans avant le scandale de Panamá, I'affaire du chemin de fer transocéanique du Honduras. Revue d'Histoire des Chemins de Fer, n. 44, p. 165-182, 2013.

CHAPMAN, Stanley D. The rise of merchant banking. London; Boston: Allen \& Unwin, 1984.

DAWSON, Frank G. The first Latin American debt crisis: the city of London and the 1822-25 loan bubble. New Haven: Yale University Press, 1990.

FERGUSON, Niall. The cash nexus: money and power in the modern world, 1700-2000. London: Allen Lane, 2001.

FLOUD, Roderick; MCCLOSKEY, Donald N. The Economic History of Britain since 1700, vol. 2. Cambridge: Cambridge University Press, 1994.

GROSSMAN, Richard. Other's people money: the evolution of Bank Capital in the Industrialized World. In: WILLIAMSON, Jeffrey G. et al (orgs.). The new comparative economic history essays in honor of Jeffrey $G$. Williamson. Cambridge: MIT Press, 2007, p. 141-164.

HOMER, Sidney; SYLLA, Richard. A History of Interest Rates. 4th. ed. New Jersey: John Wiley \& Sons, 2005.

JENKS, Leland Hamilton. The Migration of British Capital to 1875. Jonathan Cape: London, 1938.

LANDES, David S. Bankers and pashas: international finance and economic-imperialism in Egypt. Cambridge: Harvard University Press, 1958.

MARICHAL, Carlos. A century of debt crises in Latin America: from independence to the Great Depression, 1820-1930. Princeton: Princeton University Press, 1989.

MAURO, Paolo; YAFEH, Yishay. The Corporation of Foreign Bondholders. International Monetary Fund Working Papers, vol. 3, p. 32, 2003. 
JOSÉ AUGUSTO RIBAS MIRANDA

PLATT, D. C. M. Latin America and British Trade, 1806-1914. London: A. and C. Black. 1972.

SINCLAIR, David. Sir Gregor MacGregor and the Land That Never Was: The Extraordinary Story of the Most Audacious Fraud in History. London: Review. 2003.

SOWERBUTTS, Rhlannon; SCHNEEBALG, Marco; HUBERT, Florence. The demise of Overend Gurney. Quartely Bulletin of the Bank of England Press, v. Quarter 2, p. 94-116, 2016.

WOLFF, Henry Durmmond. Rambling Recollections. London: McMillian \& Co, 1908. 